\title{
TINJAUAN ATAS PENYUSUNAN DAN PENYAJIAN LAPORAN KEUANGAN MENURUT PSAK NO. 1 PADA UNO EDUCATION CENTRE MEDAN
}

\author{
Yus Epi, M.Ak \\ Politeknik Ganesha Medan \\ yusepi20november@gmail.com
}

\author{
Oki Sukrya \\ Politeknik Ganesha Medan \\ okisukrya21@gmail.com
}

\begin{abstract}
Abstrak
Laporan keuangan merupakan laporan yang memuat hasil akhir dari transaksi transaksi keuangan yang terjadi dalam suatu perusahaan. Laporan keuangan dibuat dalam satu periode akuntansi biasanya satu tahun. Laporan keuangan juga merupakan produk akhir dari proses akuntansi suatu entitas yang menjadi bahan informasi bagi para pemakainya sebagai salah satu bahan dalam proses pengambilan keputusan. Laporan keuangan terdiri dari laporan laba rugi, laporan perubahan Modal, Neraca, Laporan Arus Kas dan catatan atas laporan keuangan. Pernyataan Standar Akuntansi Keuangan (PSAK) No. 1 menetapkan seluruh persyaratan yang berguna untuk menyajikan laporan keuangan untuk kebutuhan umum, yang menguraikan pedoman untuk strukturnya, dan mendasari persyaratan minimum atas isinya dan pengungkapannya. PSAK No. 1 menetapkan karakteristik umum untuk penyajian laporan keuangan. Tujuan penelitian ini adalah untuk mengetahui penyusunan dan penyajian laporan keuangan berdasarkan Pernyataan Standar Akuntansi Keuangan (PSAK), serta kendala yang dihadapi dalam penerapannya. Penelitian ini menggunakan penelitian kualitatif dengan metode studi lapangan. Jenis data yang digunakan adalah data sekunder dengan sumber data berasal dari data internal. Hasil dalam penelitian ini menunjukkan bahwa laporan keuangan yang di susun oleh Uno Education Centre Medan tidak menerapkan sesuai dengan Pernyataan Standar Akuntansi Keuangan (PSAK) No. 1, dan hal tersebut di karenakan terbatasnya pengetahuan dan sumber daya manusia yang dimiliki
\end{abstract}

Keyword : Penyusunan dan Penyajian, Laporan Keuangan, PSAK No. 1 


\section{PENDAHULUAN}

Setiap perusahaan mempunyai aktivitas yang berbeda antara perusahaan yang satu dengan perusahaan yang lainnya baik perusahaan industri maupun perusahaan jasa dimana aktivitasnya selalu melibatkan transaksi keuangan yang memegang peranan penting dalam kelangsungan hidup perusahaan, karena keadaan perusahaan mempunyai peranan dalam kelangsungan aktivitas perusahaan tersebut.

Laporan keuangan merupakan hasil akhir yang bersumber dari suatu pengolahan data akuntansi dan dalam pembuatannya laporan keuangan merupakan informasi yang terstruktur yaitu mampu memenuhi kriteria yang relevan, dapat dimengerti, daya uji, tepat waktu, daya banding, dan lengkap. Laporan keuangan juga merupakan kesimpulan dari pencatatan transaksi yang dilakukan oleh suatu perusahaan. Laporan keuangan adalah media yang paling penting untuk menilai kondisi ekonomi dan prestasi manajemen.

PSAK No. 1 menetapkan seluruh persyaratan yang berguna untuk menyajikan laporan keuangan untuk kebutuhan umum, yang menguraikan pedoman untuk strukturnya, dan mendasari persyaratan minimum atas isinya dan pengungkapannya. Tujuan PSAK No. 1 adalah untuk memastikan informasi yang dapat diperbandingkan dengan menyajikan laporan keuangan entitas periode sebelumnya dan dengan menyajikan laporan keuangan entitas lainnya. PSAK No. 1 menetapkan karakteristik umum untuk penyajian laporan keuangan. Secara khusus, PSAK No. 1 membahas aspek-aspek; Penyajian secara wajar dan kepatuhan terhadap standar akuntansi, Kelangsungan usaha (going concern), Dasar akrual akuntansi, Materialitas, agregasi, dan saling hapus, Frekuensi pelaporan, Informasi komparatif, dan Konsistensi penyajian. Rumusan masalah berdasarkan latar belakang di atas adalah bagaimana tinjauan atas penyusunan dan penyajian laporan keuangan menurut PSAK No. 1 pada Uno Education Centre Medan? Agar pembuatan laporan ini mengarah pada yang di harapkan, maka penulis melakukan pembatasan masalah, yaitu penyusunan dan penyajian laporan keuangan pada Uno Education Centre Medan. Tujuan yang ingin di capai penulis adalah untuk mengetahui bagaimana tinjauan atas penyusunan dan penyajian laporan keuangan menurut PSAK No. 1 pada Uno Education Centre Medan.

\section{LITERATURE REVIEW}

Akuntansi adalah suatu sistem informasi yang mengukur aktivitas-aktivitas bisnis, yang selanjutnya memproses informasi tersebut dalam bentuk laporan keuangan dan mengkomunikasikannya kepada para pengambil keputusan (decesion makers) [1]. Ikatan Akuntan Indonesia [2]mengemukakan bahwa Laporan keuangan bertujuan umum (selanjutnya disebut sebagai laporan keuangan) adalah laporan keuangan yang ditujukan untuk memenuhi kebutuhan bersama sebagian besar pengguna laporan. Sedangkan menurut [3], Laporan keuangan pada dasarnya adalah Hasil dari proses akuntansi yang dapat digunakan sebagai alat untuk mengkomunikasikan data keuangan atau aktivitas perusahaan kepada pihak-pihak yang berkepentingan. tujuan penerapan PSAK No.1 adalah untukmenetapkan dasar-dasar bagi penyajian laporan keuangan bertujuan umum

Jurnal Insitusi Politeknik Ganesha Medan 
yang selanjutnya disebut laporan keuangan agar dapat dibandingkan baik dengan laporan keuangan periode sebelumnya maupun dengan laporan keuangan entitas lain. [2]

Pihak-Pihak yang Berkepentingan Terhadap Laporan Keuangan

Menurut, pihak-pihak berkepentingan terhadap laporan keuangan adalah siapa pun yang membutuhkan informasi keuangan yang tersaji pada laporan keuangan untuk mengambil keputusan. Pihak-pihak yang berkepentingan tersebut adalah:

1. Pihak Internal Perusahaan
a. Manajemen
b. Pemilik
c. Karyawan

2. Pihak Eksternal Perusahaan
a. Investor
b. Kreditur
c. Supplier
d. Pemerintah
e. Masyarakat Umum

Tujuan keseluruhan dari laporan keuangan adalah untuk memberikan informasi yang berguna bagi investor dan kreditor dalam pengambilan keputusan investasi dan kredit.

Syarat Sah Laporan Keuangan

1. Netral

2. Tepat Waktu

3. Lengkap

4. Dapat Di uji

5. Bisa Di Bandingkan

6. Memiliki Relevansi yang Baik

7. Mudah Dimengerti oleh Pihak-Pihak yang Berkepentingan

Jenis-Jenis Laporan Keuangan

1. Neraca

2. Laporan Laba Rugi

3. Laporan Perubahan Modal

4. Laporan Arus Kas

5. Catatan Atas Laporan Keuangan

\section{RESEARCH QUESTIONS}

1. Bagaimana tinjauan atas penyusunan dan penyajian laporan keuangan menurut PSAK No. 1 pada Uno Education Centre Medan?

2. Bagaimana penyajian laporan keuangan menurut PSAK No. 1 pada Uno Education Centre Medan? 


\section{METHOD}

Metode pengumpulan data dilakukan dengan cara: studi lapangan (Field Research), yaitu metode penelitian dengan cara melakukan pengamatan langsung pada perusahaan yang bersangkutan (observasi).Jenis data yang digunakan pada penelitian ini adalah: data sekunder, yaitu data yang telah disajikan oleh perusahaan untuk menjadi acuan informasi penelitian.Sumber data yang digunakan pada penelitian ini adalah: data internal, yaitu data yang diambil dari dalam pihak perusahaan.

Metode penelitian yang digunakan adalah: kualitatif deskriptif, yaitu suatu metode analisis dimana data-data yang dikumpulkan, diklasifikasikan, dianalisis dan diinterprestasikan secara objektif sehingga memberikan informasi dan gambaran mengenai topik yang akan dibahas.

\section{DISCUSSION}

Hasil penelitian dan pembahasan yang dimaksud disini merupakan data-data yang didapat oleh penulis untuk mempermudah penulis dalam penyusunan laporan keuangan, tabel berikut ini adalah tabel data yang digunakan oleh penulis :

1. Laporan Penerimaan Kas Harian dan Laporan Pengeluaran Kas Harian

2. Laporan Bank

3. Laporan Laba Rugi

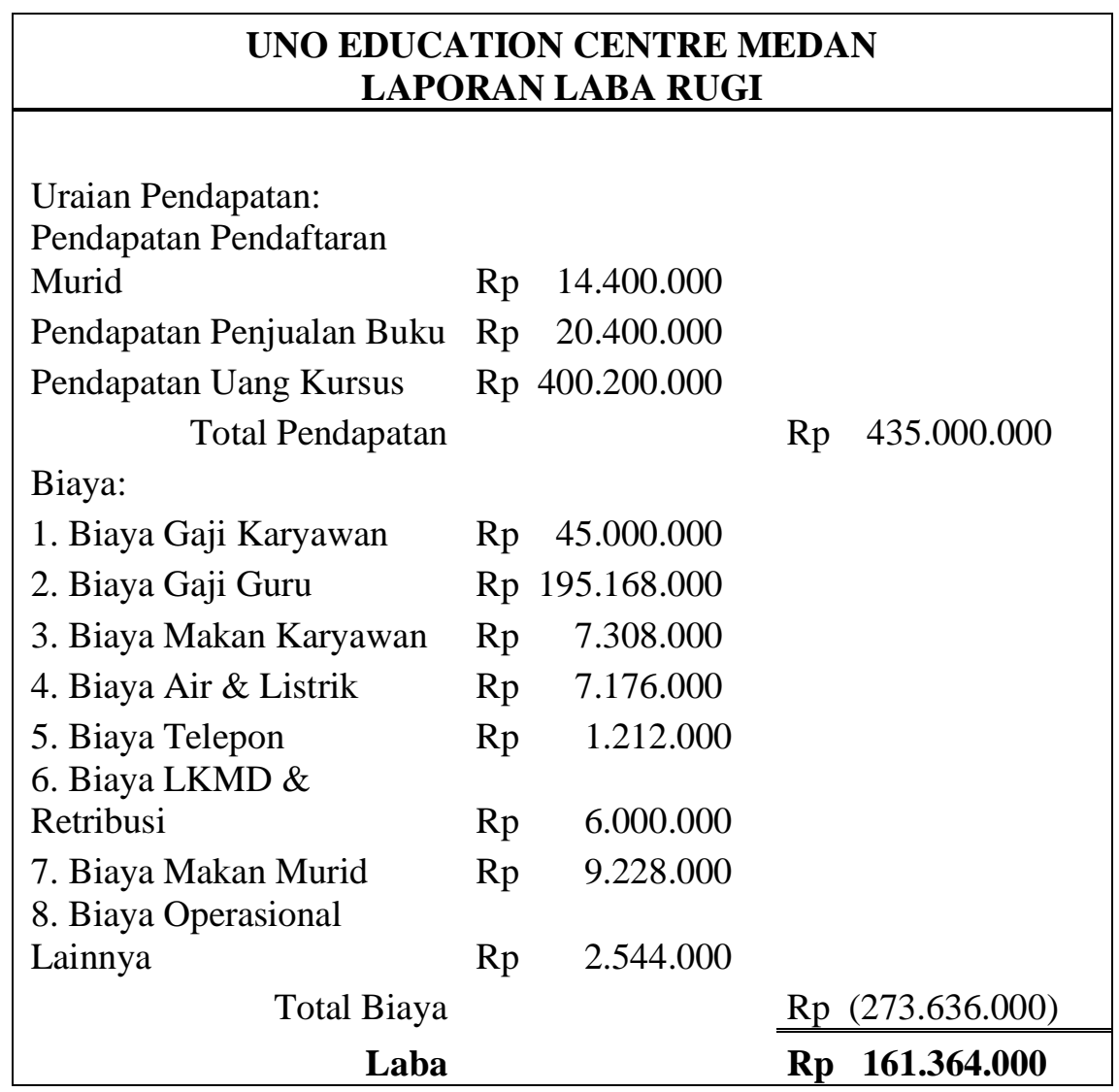

Jurnal Insitusi Politeknik Ganesha Medan 
1. Laporan Laba Rugi

\section{UNO EDUCATION CENTRE MEDAN \\ LAPORAN LABA RUGI \\ 31 Desember 2015}

Pendapatan Jasa Kursus:

Pendapatan Pendaftaran Murid $\quad$ Rp 14.400 .000

Pendapatan Penjualan Buku $\quad$ Rp 20.400 .000

Pendapatan Uang Kursus $\quad$ Rp 400.200.000

Total Pendapatan Rp 435.000 .000

Beban Operasional:

1. Beban Gaji Karyawan Rp 45.000 .000

2. Beban Gaji Guru Rp 195.168.000

3. Beban Konsumsi Karyawan Rp 7.308.000

4. Beban Konsumsi Murid Rp 9.228 .000

5. Beban Telepon Rp 1.212 .000

6. Beban Air \& Listrik Rp 7.176.000

7. Beban LKMD \& Retribusi Rp 6.000 .000

8. Beban Operasional Lainnya $\quad \mathrm{Rp} \quad 2.544 .000$

9. Beban Penyusutan Peralatan Rp 290.000

10. Beban Penyusutan Gedung Rp 12.000 .000

Total Beban Operasional $\quad \underline{R p(285.926 .000)}$

Laba $\quad$ Rp 149.074 .000

2. Laporan Perubahan Ekuitas

UNO EDUCATION CENTRE MEDAN

LAPORAN PERUBAHAN EKUITAS

31 Desember 2015

Ekuitas Awal Periode:

$\mathrm{Rp} \quad 2.466 .866 .000$

Laba: $\quad$ Rp 149.074 .000

Kenaikan Ekuitas

$\mathrm{Rp} \quad 149.074 .000$

EKUITAS AKHIR PERIODE

Rp $\quad 2.615 .940 .000$

3. Neraca

Jurnal Insitusi Politeknik Ganesha Medan

146

Juripol, Volume 4 Nomor 2 September 2021 


\begin{tabular}{|c|c|c|c|}
\hline \multicolumn{4}{|c|}{$\begin{array}{c}\text { UNO EDUCATION CENTRE MEDAN } \\
\text { NERACA } \\
\text { 31 Desember } 2015 \\
\end{array}$} \\
\hline \multicolumn{4}{|l|}{ ASET } \\
\hline \multicolumn{4}{|l|}{ ASET LANCAR } \\
\hline Kas & $\mathrm{Rp}$ & 299.292.000 & \\
\hline Perlengkapan & $\mathrm{Rp}$ & 9.958 .000 & \\
\hline Persediaan Buku & $\underline{\mathrm{Rp}}$ & 3.200 .000 & \\
\hline Total Aset Lancar & & & Rp 312.450.000 \\
\hline \multicolumn{4}{|l|}{ ASET TETAP } \\
\hline $\begin{array}{l}\text { Peralatan } \\
\text { Akumulasi Penyusutan }\end{array}$ & $\mathrm{Rp}$ & 29.000 .000 & \\
\hline Peralatan & $\mathrm{Rp}$ & $(5.510 .000)$ & \\
\hline $\begin{array}{l}\text { Gedung } \\
\text { Akumulasi Penyusutan }\end{array}$ & $\mathrm{Rp}$ & 2.400 .000 .000 & \\
\hline Gedung & $\underline{\mathrm{Rp}}$ & $(120.000 .000)$ & \\
\hline Total Aset Tetap & & & Rp 2.303.490.000 \\
\hline TOTAL ASET & & & Rp 2.615.940.000 \\
\hline $\begin{array}{l}\text { EKUITAS } \\
\text { EKUITAS AKHIR } \\
\text { PERIODE } \\
\end{array}$ & & & Rp 2.615.940.000 \\
\hline
\end{tabular}

4. Laporan Arus Kas

\section{UNO EDUCATION CENTRE MEDAN \\ LAPORAN ARUS KAS \\ 31 Desember 2015}

Laba Bersih

Rp 149.074.000

Aktivitas Operasi:

Kenaikan Perlengkapan $\quad \mathrm{Rp} \quad(9.958 .000)$

Kenaikan Persediaan Buku Rp (3.200.000)

Kenaikan Akumulasi

Penyusutan Peralatan

$\mathrm{Rp} \quad 5.510 .000$

Kenaikan Akumulasi

Penyusutan Gedung

Rp $\quad 120.000 .000$

Rp 112.352.000

Aktivitas Investasi:

Kenaikan Peralatan

Rp (29.000.000)

Jurnal Insitusi Politeknik Ganesha Medan

Juripol, Volume 4 Nomor 2 September 2021 
Kenaikan Gedung

Aktivitas Pendanaan:

Modal
$\underline{\operatorname{Rp}(2.400 .000 .000)} \mathbf{R p}$

(2.429.000.000)

\begin{tabular}{|cr}
\multicolumn{1}{c}{2.466 .866 .000} & \\
& Rp2.466.866.000 \\
Kenaikan Kas & Rp 299.292.000 \\
\hline
\end{tabular}

Dapat terlihat jelas perbedaan antara laporan laba rugi yang di susun oleh Uno Education Centre Medan dengan laporan laba rugi yang sesuai dengan PSAK No. 1. Laba yang tercatat pada laporan laba rugi yang di susun oleh pihak perusahaan adalah sebesar Rp 161.364.000 sementara laba yang tercatat pada laporan laba rugi yang sesuai dengan PSAK No.1 adalah Rp 149.074.000. Terdapat selisih Rp 12.290.000. Hal ini di karenakan adanya pencatatan beban penyusutan peralatan sebesar Rp 290.000 dan beban penyusutan gedung sebesar Rp 12.000.000 pada laporan laba rugi yang sesuai dengan PSAK No. 1. Pihak perusahaan tidak melakukan pencatatan tentang penyusutan ataupun akumulasi penyusutan. Kurangnya pengetahuan tentang hal tersebut di karenakan sumber daya yang di miliki Uno Education Centre Medan kurang memiliki pengetahuan tentang laporan keuangan yang sesuai dengan standar

\section{CONCLUSIONS}

Dari hasil penelitian yang telah dilakukan tentang penyusunan dan penyajian laporan keuangan berdasarkan PSAK No. 1 pada Uno Education Centre Medan, maka dapat disimpulkan sebagai berikut:

1. Laporan keuangan yang disusun oleh Uno Education Centre Medan adalah laporan penerimaan kas harian dan pengeluaran kas harian, laporan bank, dan laporan laba rugi. Uno Education Centre Medan belum menyajikan laporan keuangan yang sesuai dengan PSAK, begitu juga dengan laporan laba rugi.

2. Penyusunan dan penyajian laporan keuangan berdasarkan PSAK No. 1 dimulai dari mengumpulkan bukti transaksi, menganalisis transaksi, mencatat transaksi dalam bentuk jurnal, memposting ke buku besar, membuat neraca saldo, membuat ayat jurnal penyesuaian, menyusun neraca saldo setelah disesuaikan, kemudian membuat laporan keuangan yang dimulai dari laporan laba rugi, laporan perubahan ekuitas, neraca, dan laporan arus kas.

3. Dari semua siklus akuntansi (transaksi sampai dengan laporan keuangan), Uno Education Centre Medan sama sekali tidak ada menerapkan laporan keuangan yang sesuai dengan PSAK No.1.

4. Kurangnya kesadaran pihak perusahaan akan pentingnya laporan keuangan yang lengkap dan sesuai standar. 


\section{Daftar Pustaka}

[1] M. J. Wantah, "Penerapan PSAK No.1 Tentang Penyajian Laporan Keuangan Pada Perum Bulog Divre Sulut dan Gorontalo," JUrnal Berkala Ilmiah Efisiensi, vol. 15 Nomor 04, no. 2015, pp. 74-88, 2015.

[2] I. A. Indonesia, PSAK 1 Penyajian Laporan Keuangan, Jakarta: iaiglobal.or.id, 2015.

[3] Hery, Mengenal dan Memahami Dasar-dasar Laporan Keuangan, Jakarta: Kompas Gramedia, 2016.

[4] R. Ariefiansyah dan M. U. Miyosi, Mmbuat Laporan Keuangan Gampang, Jakarta: Dunia Cerdas, 2013.

[5] Deanta, Memahami Pos Pos dan Angka dalam Laporan Keuangan untuk Orang Awam, Yogyakarta: Grava Media, 2016.

[6] Hery, Akuntansi Dasar, Jakarta: PT Grasindo, 2016.

[7] Hery, Akuntansi Keuangan Menengah, Yogyakarta: Center of Academic Publishing Service, 2013.

[8] R. H. Lubis, Pengantar Akuntansi Jasa Berbasis SAK IFRS dan SAK ETAP, Medan: Gava Media, 2017.

[9] A. L. Sadeli, Dasar-dasar Akuntansi, Jakarta: Bumi Aksara, 2015.

[10] A. P. Sari, Penyusunan dan Penyajian Laporan Keuangan Berdasarkan Standar Akuntansi Keuangan Entitas Tanpa Akuntabilitas, -: Portal Garuda.org, 2014.

[11] S. Syakur, Intermediate Accountung, Jakarta: A V Publisher, 2015.

[12] A. Wind, Jurus Kilat Membuat Laporan Keuangan PT, CV, Persero, Jakarta: Dunia Cerdas, 2014. 